\section{B A Institute of \\ YK Business Administration \\ 帘 \\ Karachi \\ Leadership and Ideas for Tomorrow}

Business Review

Volume 2 Issue 1 January - June 2007

$1-1-2007$

\title{
Innovation studies in different countries: Future research agenda for Pakistan
}

Syed Awais Ahmad Tipu

Institute of Business Administration, Karachi, Pakistan.

Follow this and additional works at: https://ir.iba.edu.pk/businessreview

Part of the Scholarship of Teaching and Learning Commons

(c) (i)

This work is licensed under a Creative Commons Attribution 4.0 International License.

\section{Recommended Citation}

Tipu, S. A. (2007). Innovation studies in different countries: Future research agenda for Pakistan. Business Review, 2(1), 171-180. Retrieved from https://doi.org/10.54784/1990-6587.1120

This article is brought to you by iRepository for open access under the Creative Commons Attribution 4.0 License and is available at https://ir.iba.edu.pk/businessreview/vol2/iss1/13. For more information, please contact irepository@iba.edu.pk. 


\title{
DISCUSSION
}

\section{Innovation Studies in Different Countries: Future Research Agenda for Pakistan}

\author{
Syed Awais Ahmad Tipu \\ Institute of Business Administration, Karachi, Pakistan.
}

\begin{abstract}
This paper presents a selected literature review on innovation management practices in different countries. A tabular analysis of previous case studies is presented. The paper also presents the overview of innovation surveys which have been conducted in selected countries using the Oslo manual guidelines developed by the OECD. Different studies show the innovation management practices of firms operating in various countries. However, little is known about the present state of innovation management activities in Pakistan. This paper will set forth the future research agenda for Pakistan with regard to managing innovation.
\end{abstract}

Keywords: Innovation Management, Organizational Behavior, Technology Management, Organizational Culture

\section{INTRODUCTION}

A ccording to Porter (1990), innovation includes "both new technologies and new

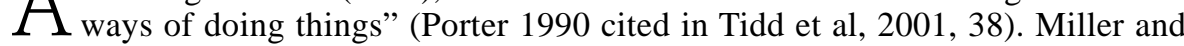
Morris defined innovation as "the process of transforming an invention into something commercially useful and valuable" (Miller and Morris 1999 cited in Kane and Ragsdell 2003, 1).

Various authors argued that the economic development of different nations was the result of technological innovations (Chandler 1990; Diamond 1997; Landes 1998; Tushman and Anderson 2004). Diamond (1997) and Landes (1998) stated that the societal receptivity is critical for the success of innovation. Gault (2003) also mentioned that the innovation could be beneficial for the society at large by means of encouraging economic development. Some countries offer more conducive environment in which innovations could flourish (Afuah 2003; Chandler 1990; Diamond 1997; Landes 1998). Slazar and Holbrook (2004) suggested that the research should also focus on the noninnovative behavior and innovation failures in addition to innovation success stories.

\section{INNOVATION SURVEYS IN DIFFERENT COUNTRIES}

The following section presents the overview of innovation surveys in different countries.

\section{Innovation Surveys based on OECD Oslo Manual}

The Organization for Economic Cooperation and Development (OECD) has developed guidelines called Oslo Manual in order to collect and interpret innovation data (OECD 
1997). The Oslo Manual provides guidelines to collect data concerning firm size, expenditure on innovation, sources of innovative ideas, role of public policy, economic and organizational aspects of innovation. However, it does not fully address other societal factors such as national culture, poverty, corruption, quality of life, trust, and organizational factors such as firms' strategy and structure, rewarding innovation and risk taking.

The innovation surveys based on Oslo Manual have been conducted in various OECD member countries including Germany, France, Australia, Italy and Canada. The first innovation survey (known as European Community Innovation Survey) based on Oslo Manual was conducted in Europe in 1992 (Salazar and Holbrook 2004). Various countries in Latin America that have initiated innovation surveys based on Oslo Manual include Chile, Colombia, Venezuela, Argentina and Brazil. The initial innovation surveys conducted in Latin American countries found Latin firms less innovative because these firms pursued few research and development activities due to resource scarcity (Salazar and Holbrook 2004).

The recent Community Innovation Survey was conducted in Europe in 2001 based on Oslo Manual guidelines. The research institutes in member countries collected the data. The non-technical aspects of innovation are now being incorporated in the Oslo Manual for future innovation surveys. These non-technical aspects include organizational, management and marketing aspects of innovation (European Communities 2004). The following are some of the findings of this survey:

- 47 percent of European Union industrial enterprises carried out innovation activity during 1998-2000.

- 59 percent of enterprises in manufacturing implemented both product and process innovations.

- 21 percent of enterprises mentioned that innovation costs were too high.

- 15 percent mentioned perceived economic risk as innovation hampering factor and 15 percent mentioned lack of finances as impeding factor.

- 13 percent mentioned lack of qualified staff hampered innovation.

Salazar and Holbrook (2004) criticized the Oslo Manual guidelines and said that the innovation surveys are more focused on measuring innovation and do not fully address the environmental and societal factors that may influence innovation. They further said that innovation surveys lack information concerning innovation diffusion and fail to explain the linkages among different entities in an innovation system. Salazar and Holbrook (2004) emphasized the importance of studying non-innovative behavior and innovation failures and said that innovation surveys are more concerned with innovation success stories.

\section{Innovation Systems Research Network (ISRN) Canada}

A network of researchers, known as Innovation Systems Research Network (ISRN) in Canada is currently involved in an innovation survey that encompasses five regions 
in Canada. This innovation survey was launched in 2001 covering five regional nodes including Atlantic Canada, Quebec, Ontario, Western Canada, and National Capitol Region. The focus of this innovation survey is to evaluate the role and relationship of clusters in the regional innovation systems. A total of 27 clusters are participating in the study (Salazar and Holbrook 2004).

The representatives of government, private sector, and international community are participating in this study funded by the Social Science and Humanities Research Council of Canada. The data collection methods include surveys and interview based case studies. The data collected from an earlier survey know as "Statistics Canada" which was conducted during 1999, is also being used. The expected completion data of this survey was fourth quarter of 2005. The participating clusters include biotech, wireless, wood products, food and beverages, information technology, auto, steel, and aerospace (ISRN 2001).

\section{Innovation Survey in Finland}

Palmberg et al (2000) examined 1482 Finnish innovations that were commercialized during 1980-1990 in order to highlight the significance of different factors such as collaboration, public support, and firm size. The data was collected based on expert opinion, publications and annual reports of the participating firms. A total of 18 trade related Finnish journals were used to gather innovation data. According to the findings of this survey, large firms were more inclined to establish relationship with universities for collaborative research. Small firms were dependent on public funding for innovative activities. Finnish firms were focusing more on collaboration and gave importance to the customer's relationship and focusing on specific market segment in order to have better customer satisfaction. Finnish firms preferred to work with domestic partner as compared to foreign partners. Finnish companies were also able to launch half of the studied innovations in the market place in less than two years from the time of basic generation. About 30 percent of the innovations were not exported and about 40 percent were not able to break-even (Palmberg et al 2000).

\section{Innovation Survey in Australia}

The innovation survey in Australia was conducted by Australian Bureau of Statistics (ABS) based on Oslo Manual guidelines developed by OECD. This survey was conducted during 2001-2003 and the questionnaires were mailed to 8500 businesses. According to the survey results, about 34 percent firms carried out technological innovations. Large companies (100 or more employees) were more innovative as compared to small companies (5-19 employees). The businesses in manufacturing industry spent the most (27 percent) on innovative projects and about 62 percent businesses mentioned cost as a significant barrier to innovation (Australian Bureau of Statistics 2005).

\section{National Innovation Initiative, United States}

The Council on Competitiveness, a non-profit organization, launched a study named "National Innovation Initiative" in 2003. This study was a team effort of Georgia 
Institute of Technology and IBM. The objective of this initiative was to explore how America could maintain its technological leadership in the world and what are the areas that need improvement to face the challenge of the 21 st century. A total of about 400 leaders participated in this think tank (Council on Competitiveness 2005).

The Council on Competitiveness published its final report in December 2004. This report particularly highlighted three areas that are critical to the American technological leadership in the future and need improvement. These areas include:

1) Talent: Culture of collaboration, life long skill development and commercial orientation of research

2) Investment: Resource availability. Incentives for innovation

3) Infrastructure: Strong linkage between Industry-Academia, effective intellectual property protection

The report pinpointed that America is facing stiff competition and the society as a whole should respond to face this challenge in order to maintain the leadership position in 21st century (Council on Competitiveness 2004).

\section{CASE STUDIES OF INNOVATION MANAGEMENT PRACTICES AT THE ORGANIZATION LEVEL}

A selected literature review was conducted to identify previous case studies with the focus on the innovation management practices in different countries. The results are summarized in table I.

\section{Selected innovation practices at firm level}

In the context of case "A", (Atherton and Hannon 2000) says that in order to be successful, firms must have innovation strategy and other capabilities like a pool or library of ideas, technical expertise and business management know-how. The case "B" reflected the importance of internal funds for financing innovative projects and the importance of the role of top management (Lehtimaki 1991).

The case study " $C$ " showed that the coworkers often originate innovative ideas in small firms and the suppliers are main source of innovative ideas in large firms (Bommer and Jalajas 2004). The case study "D" concluded that the most significant barriers to innovation are lack of finances, lack of trust and identification of suitable partners (Freel 2000). These factors have critical implications for companies operating in developing countries. The European case study "E" showed that the firm's ability to innovate increases if the firm is engaged in R\&D activity intensively and has qualified personnel on board (Caloghirou et al 2004).

According to the case study " $F$ ", the organizations must have an effective communication mechanism in order to nurture innovation. The study also identified that the team spirit, mutual trust, low interpersonal conflict, cross-functional support, management support, personal rewards, and recognition enhance innovativeness of $R \& D$ teams 
(Thamhain 2003). Thamhain (2003) further characterized the external as well as internal factors that influence innovation performance. The internal factors are leadership, organizational environment, people, processes, strategy, tasks, technology, tools and techniques. One important point of consideration is to investigate the implications for managers operating in developing countries in the context of internal factors? Do they practice these innovation management techniques or not? Can firms practice these techniques while operating in an unstable external environment?

In the context of case "G", Keller and Holland $(1983,746)$ found that the innovators had "a low need of clarity, and high self-esteem. In addition, they tended to have a higher level education, to read more work related journals and periodicals." Furthermore, they also suggested that the management should encourage a physical layout that fosters mutual interaction and facilitates the flow of information. This can be achieved by proper clustering of offices, building common lounge areas, and common eatingplaces. This kind of setup will encourage the mingling of employees and sharing of knowledge.

According to the case study " $\mathrm{H}$ " conducted in US and Canada, the relationships have significant importance as far as innovation implementation is concerned. In this context, the peer group is the most important relationship that is essential for smooth implementation of innovative project (Linton 2000). The case study "I" was primarily focused on the effects of a hostile environment and uncertainty on the organizational structure and strategic posture (Ozsomer et al 1997). This relationship is particularly significant in the case of the organizations operating in the developing world because they operate in an uncertain and hostile environment. Depending upon the external environmental circumstances, the organizations adopt appropriate strategic posture: aggressive, proactive, or reactive.

Ozsomer et al (1997) found that firms were more proactive in highly uncertain environment and that a highly hostile environment forced companies to have a reactive posture. This study was conducted on Fortune 500 companies, so there are serious implications for firms in developing countries to be proactive. However, little is known about how organizations will encourage creativity within the boundaries of organizations if they have a reactive posture. Are organizations in the developing world willing to embrace the innovation management techniques of the developed world's organizations? Is the organizational structure of firms in developing countries flexible enough to nurture innovation?

(Saleh and Wang 1993) reported the results of their study "J" conducted in Canada. They tried to identify factors that differentiate innovative firms from less innovative firms. They identified the following parameters:

Calculated risk taking, commitment to entrepreneurial activities and innovation, integration and intermingling of talents in teams and tasks forces, group and collective orientation, and a reward system that reinforce entrepreneurial behavior. (Saleh and Wang 1993, 20) 


\section{INNOVATION STUDIES IN PAKISTAN}

The objective of the literature review was to determine previous innovation studies in Pakistan. No significant innovation study on industrial sector of Pakistan was found. Qureshi (1983) completed a research study on cotton textile sector of Pakistan with the focus on inter-firm innovation diffusion. The research was quantitative and was focused on factors that may influence technology transfer among firms in the same industry. He underlined factors such as firm size, growth rate of the firms, competition, vertical integration and international connections and analyzed their impact on firms' decision to adopt new technology such as shuttleless looms (a kind of loom that result in lower unit cost). He found that the firms' international connection is the crucial factor in adopting new technology. However, this research does not explain whether technical organizations in Pakistan encourage organizational innovation at the organization level and how various other factors such as geographical and regional, political and legal, organizational structure, organizational culture, and people could influence organizational capability to innovate.

Pakistan Council for Science and Technology (PCST) conducted research to identify the productive scientists of Pakistan. The study reviewed different scientists based on their recent publications. Most of the organizations studied in this study were 47 public sector universities and 100 major research and development organizations. The study was heavily focused on public sector and found that only seven centers conduct international level research (The News 2004). The Asian Technology information Program (ATIP 1998) reported that there is a weak linkage between industry and public sector research institutions in Pakistan, because the research activities were not focused on exploiting the commercial potential of research outcome. This report was also heavily focused on government and universities' research activities and not on industry's perspective on managing innovation in Pakistan.

\section{CONCLUSIONS}

Based on the review of the literature, it appeared that there is no significant innovation study that underscores the current state of innovation in Pakistan. There was a paucity of research that examined various social, legal, cultural, technological and people factors which could deter or encourage innovation in Pakistan. It is suggested that future research should be conducted both at the country level and the organization level in order to highlight the innovation management practices in Pakistan. The guidelines of the Oslo Manual developed by OECD could be used to conduct the innovation surveys in Pakistan. Different research approaches mentioned in Table I suggest the tracks that could be considered for future research studies in Pakistan. 
Table I: Survey Comparison: Innovation Management Practices

\begin{tabular}{|c|c|c|c|c|c|c|}
\hline Case & Country & $\begin{array}{l}\text { Sample } \\
\text { Size }\end{array}$ & $\begin{array}{l}\text { Type of } \\
\text { Respondents }\end{array}$ & $\begin{array}{l}\text { Data Collection } \\
\text { Method }\end{array}$ & $\begin{array}{l}\text { Study } \\
\text { Focus }\end{array}$ & $\begin{array}{l}\text { Key } \\
\text { Findings }\end{array}$ \\
\hline $\mathrm{A}$ & $\begin{array}{l}\text { UK (large, } \\
\text { medium, small } \\
\text { firms) }\end{array}$ & $\begin{array}{l}5 \text { cases- } \\
\text { firms }\end{array}$ & Owner & Interview & Innovation process & Innovation strategy \\
\hline B & Finland & 40 cases & $\begin{array}{l}\text { Unknown } \\
\text { 1-260 employees }\end{array}$ & $\begin{array}{l}\text { Structured interview } \\
\text { using questionnaire } \\
\text { deign }\end{array}$ & Innovation process & $\begin{array}{l}\text {-Role of top management } \\
\text {-Internal funds }\end{array}$ \\
\hline $\mathrm{C}$ & US & 235 & R\&D workers & Questionnaire & Sources of innovation & $\begin{array}{l}\text { SME }=\text { coworkers } \\
\text { Large }=\text { suppliers }\end{array}$ \\
\hline $\mathrm{D}$ & UK & 238 (SMEs) & $\begin{array}{l}\text { Full time } \\
\text { employees }\end{array}$ & Postal questionnaire & $\begin{array}{l}\text { Barriers to product } \\
\text { innovation }\end{array}$ & $\begin{array}{l}\text { Finances, lack of trust and } \\
\text { identification of suitable } \\
\text { partner }\end{array}$ \\
\hline$E$ & $\begin{array}{l}\text { Greece, } \\
\text { Italy, } \\
\text { Denmark, } \\
\text { UK, } \\
\text { France, } \\
\text { Germany, the } \\
\text { Netherlands }\end{array}$ & 558 & $\begin{array}{l}\text { R\&D managers } \\
\text { (SMEs) }\end{array}$ & $\begin{array}{l}\text { Telephone interview } \\
\text { questionnaire }\end{array}$ & $\begin{array}{l}\text { Internal capabilities \& } \\
\text { interaction with external } \\
\text { sources of knowledge }\end{array}$ & $\begin{array}{l}\text {-R\&D intensity } \\
\text {-Personnel qualification }\end{array}$ \\
\hline $\mathrm{F}$ & $\begin{array}{l}\text { US Fortune } \\
500 \\
\text { companies } \\
\text { (27 firms) }\end{array}$ & $\begin{array}{l}74 \text { project } \\
\text { teams }\end{array}$ & $\begin{array}{l}\text { Project leader } \\
\text { Team members }\end{array}$ & $\begin{array}{l}\text { Questionnaire } \\
\text { Observation } \\
\text { Interview }\end{array}$ & $\begin{array}{l}\text { Factors influencing } \\
\text { performance of } R \& D \\
\text { teams }\end{array}$ & $\begin{array}{l}\text {-Effective communication } \\
\text {-Team spirit, mutual trust } \\
\text {-Low interpersonal conflict } \\
\text {-Cross-functional support } \\
\text {-Management support } \\
\text {-Personal rewards } \\
\text {-Recognition }\end{array}$ \\
\hline $\mathrm{G}$ & $\begin{array}{l}\text { US (3 applied } \\
\text { R\&D } \\
\text { organizations) }\end{array}$ & $\begin{array}{l}256 \\
\text { employees } \\
\text { at time one }\end{array}$ & $\begin{array}{l}\text { Professional } \\
\text { employees }\end{array}$ & Questionnaire & $\begin{array}{l}\text { Innovators' individual } \\
\text { characteristics and impact } \\
\text { of physical layout }\end{array}$ & $\begin{array}{l}\text { - Read work related journals } \\
\text { - Clustering of offices } \\
\text { - Common lounge areas } \\
\text { - Common eating places }\end{array}$ \\
\hline $\mathrm{H}$ & $\begin{array}{l}\text { US } \\
\text { Canada }\end{array}$ & 129 projects & Project leaders & $\begin{array}{l}\text { Mail survey } \\
\text { Telephone interview }\end{array}$ & $\begin{array}{l}\text { Role of relationships and } \\
\text { innovation implementation }\end{array}$ & -Peer Group \\
\hline I & $\begin{array}{l}\text { US -Fortune } \\
500 \\
\text { companies }\end{array}$ & 346 & Senior managers & Questionnaire & $\begin{array}{l}\text { Effects of environmental } \\
\text { uncertainty on the firms } \\
\text { organizational structure } \\
\text { and strategy posture }\end{array}$ & $\begin{array}{l}\text { - Hostile environments lead } \\
\text { to reactive posture } \\
\text { - Flexible structure make } \\
\text { firms more innovative } \\
\text { - Proactive postures make } \\
\text { firms significantly more } \\
\text { innovative }\end{array}$ \\
\hline $\mathrm{J}$ & Canada & 43 & $\begin{array}{l}\text { Senior } \\
\text { executives } \\
\text { Technical staff }\end{array}$ & Questionnaire & $\begin{array}{l}\text { Factors that differentiate } \\
\text { innovative and less } \\
\text { innovative companies }\end{array}$ & $\begin{array}{l}\text { - Calculated risk taking } \\
\text { - Intermingling of talents in } \\
\text { teams } \\
\text { - Reward system }\end{array}$ \\
\hline
\end{tabular}




\section{REFERENCES}

Afuah, A. (2003), Innovation Management: Strategies, Implementation, and Profits, Oxford University Press Inc., New York, NY.

Asian Technology Information Program (1998), Science and Technology Overview in Pakistan, http://www.atip.org/public/atip.reports.98/atip98.049r.html (accessed March 10, 2004).

Atherton, Andrew and Hannon, Paul (2000), Innovation process and the small business: A conceptual analysis. International Journal of Business Performance Management, 2(4), 276-292.

Australian Bureau of Statistics (2005), More than One Third of Businesses are Innovators, http://www.abs.gov.au/Ausstats/abs@.nsf/0/222bd10c221fbabbca256faa007bb1fe? OpenDocument (accessed May 14, 2005).

Bommer, Michael and Jalajas, David (2004), Innovation sources of large and small technology-based firms, IEEE Transactions on Engineering Management, 51(1), 13-18.

Caloghirou, Yannis; Kastelli, Ioanna; Tsakanikas, Aggelos (2004), Internal capabilities and external knowledge sources: Complements or substitutes for innovation performance. Technovation, 24(1), 29-39.

Chandler, A. (1990), Scale and Scope: The Dynamics of Industrial Capitalism, Harvard University Press, Cambridge, MA.

Council on Competitiveness (2004), Innovate America: Thriving in a World of Challenge and Change, http://www.compete.org/pdf/NII_Interim_Report.pdf (accessed May 14, 2005).

Ibid, (2005), Innovate America: Thriving in a World of Challenge and Change, http://www.compete.org/newsroom/readnews.asp?id=272 (accessed May 11, 2005).

Diamond, J. (1997), Guns, Germs and Steel: The Fate of Human Societies, W.W. Norton and Co, New York, NY.

European Communities (2004), Community Innovation Survey, http://www.cordis.lu/innovation-smes/src/cis.htm (accessed May 11, 2005).

Eurostat, Statistical Office of the European Communities (2004), Innovation in Europe: Results for the EU, Iceland and Norway, http://epp.eurostat.cec.eu.int/cache/ITY_OFFPUB/KS-59-04-257/FR/KS-59-04-257FR.PDF (accessed May 14, 2005). 
Freel, Mark (2000), Barriers to product innovation in small manufacturing firms. International Small Business Journal, 18(2), 60-80.

Gault, F. (2003), Understanding Innovation in Canadian Industry, McGill-Queen's University Press, Montreal and Kingston.

ISRN, Innovation Systems Research Network, Center for International Studies at the University of Toronto (2001), Clusters Initiative, http://www.utoronto.ca/isrn/clusters.htm (accessed May 14, 2005).

Keller, Robert; Holland, Winford (1983), Communicators and innovators in research and development organizations, The Academy of Management Journal, 26(4), 742-749.

Landes, D. (1998), The Wealth and Poverty of Nations: Why Some are So Rich and Some are So Poor, W.W. Norton and Co., New York, NY.

Lehtimaki, Allan (1991), Management of innovation process in small companies in Finland. IEEE Transactions on Engineering Management, 38(2), 121-126.

Linton, Jonathan (2000), The role of relationship and reciprocity in the implementation of process innovation, Engineering Management Journal, 12(3), 34-38.

OECD, Organization for Economic Co-operation and Development (1997), The Measurement of Scientific and Technological Activities: Proposed Guidelines for Collecting and Interpreting Technological Innovation Data, Oslo Manual, OECD, Paris.

Ozsomer, Aysegul; Calantone, Roger; Benedetto, Anthony (1997), What makes firms more innovative?, A look at organizational and environmental factors. Journal of Business and Industrial Marketing, 12(6), 400-416.

Palmberg, C., Niininen, P., Toivanen, H., and Wahlberg, T. (2000), Industrial Innovation in Finland, http://virtual.vtt.fi/inf/julkaisut/muut/2000/wp47.pdf (accessed May 14, 2005).

Porter, M. (1990), The Competitive Advantage of Nations, The Free Press, London.

Qureshi, M. (1983), Diffusion of Technological Change: Case of the Shuttleless Loom in the Cotton Textile Industry in Pakistan, Ph.D. Thesis, Rensselaer Polytechnic Institute, Troy, NY.

Salazar, M., and Holbrook, A. (2004), A Debate on Innovation Surveys, Science and Public Policy, 31(4), pp. 254-266. 
Saleh, Shoukry; Wang, Clement (1993), The management of innovation: Strategy, structure, and organizational climate. IEEE Transactions on Engineering Management 40(1), 14-21.

Thamhain, Hans (2003), Managing innovative R\&D teams, R\&D Management, 33(3), 297-311.

The News (2004), Atta Ranked Top Productive Scientist of Country, http://www.jang.com.pk/thenews/feb2004-daily/23-02-2004/metro/i2.htm (accessed August 4, 2004).

Tidd, J., Bessant, J., and Pavitt, K. (2001), Managing Innovation: Integrating Technological, Market and Organizational Change, John Wiley \& Sons, England.

To go from good to great requires transcending the curse of competence. It requires the discipline to say, "Just because we are good at it - just because we're making money and generating growth - doesn't necessarily mean we can become the best at it." The good-to-great companies understood that doing what you are good at will only make you good; focusing solely on what you can potentially do better than any other organization is the only path to greatness.

Jim Collins 